\title{
Carta ao Leitor
}

O sistema de ensino, principalmente no âmbito da formação superior, deve hoje estar voltado para as massas ou para a elite, mesmo considerando-se o sentido atual desta última palavra, que designa as camadas portadoras do conhecimento e da capacidade e não apenas da riqueza? A questão é levantada por Laurent Schwartz, presidente do Comitê Nacional de Avaliação, de Paris, que dimensiona os gastos e investimentos com ensino nos países desenvolvidos e mostra a necessidade de uma diferenciação, mesmo entre as universidades, na busca da excelência e da qualidade para uma formação no mais alto nível possível.

Partindo da colocação desta realidade, José Goldemberg e Elisa Wolynec traçam um paralelo com a realidade brasileira, onde um estudante chega a custar, para a Universidade de São Paulo, US $\$ 4.000 / a n o$ enquanto o custo médio, na França, chega a US\$1.700/ano. A problemática não se restringe, naturalmente, à USP mas a todo o sistema de ensino do País, como mostra Braz José de Araujo em seu artigo "Em Torno de um Conceito Atual de Universidade" Para o professor, não existiu e ainda não existe uma política coerente em relação às universidades do Brasil, e a própria USP tem pela frente desafios básicos: consolidação do sistema de mérito, flexibilidade organizacional e institucional e capacidade para atender às consultas do sistema produtivo e da própria sociedade como um todo.

A Revista da USP traz, ainda nesta edição, artigo de Fernando Augusto Albuquerque Mourão, com comentário analítico da obra de Mariano Carneiro da Cunha "Da Senzala ao Sobrado: Arquitetura Brasileira da Nigéria e na República Popular do Benin" onde mostra as influências da arquitetura brasileira colonial num contexto da cultura iorubá. "O Tribunal da Inquisição em Portugal" é tema de artigo de Anita Novinsky, enquanto Osvaldo Coggiola analisa as inovações de Antônio Gramsci, no campo da sociologia marxista, e o seu objetivo principal: o esclarecimento das condições históricas para a revolução proletária.

José Cesar Gnaccarini faz uma investigação da contribuição de Florestan Fernandes em seu artigo "Folclore e Consciência Nacional: a visão crítica de Florestan Fernandes" e, na seção Debate, criada nesta edição, José Carlos Sebe Bom Meihy entrevista o antropólogo Charles Wagley, decano dos brasilianistas. A Revista tem ainda a participação de Eunice Ribeiro Durham, Diogo Pupo Nogueira, Jorge da Rocha Gomes e Willi Bolle.

A partir desta edição, além de algumas alterações de caráter editorial, como a criação de novas seções, a Revista da USP passa a contar com um serviço de assinatura anual. 